\title{
Chronic Neutropenia and Defect in Superoxide Generation of Granulocytes in Two Patients: Enhancement of Bactericidal Capacity and Respiratory Burst Activity by Treatment with Recombinant Human Granulocyte Colony-Stimulating Factor
}

\author{
RITA KÁPOSZTA AND LÁSZLÓ MARÓDI
}

Division of Immunology, Department of Pediatrics, University School of Medicine, Debrecen, Hungary

\section{ABSTRACT}

We have identified two unrelated girls with chronic neutropenia [absolute neutrophil counts (ANC) 10-870 and 10$940 / \mu \mathrm{L}$ in patients 1 and 2 , respectively] and severe defect in superoxide anion generation by granulocytes. Formyl-methionylleucyl-phenylalanine-induced superoxide release was $1.2 \pm 0.9$ and $1.9 \pm 1.9 \%$ (mean $\pm \operatorname{SEM}, n=3$ ) of normal controls', mean value in patients 1 and 2 , respectively. However, granulocytes from both patients released a normal amount of superoxide upon stimulation with phorbol myristate acetate. Patient 2 exhibited characteristic features of Duane syndrome, a rare disorder of eye movement. Treatment of the patients with recombinant granulocyte colony-stimulating factor led to significant clinical improvements and reduction of infectious complications and to increases in the ANC, to $400-2100 / \mu \mathrm{L}$ in patient 1 and to $500-3000 / \mu \mathrm{L}$ in patient 2. Treatment with $5 \mu \mathrm{g} / \mathrm{kg} / \mathrm{d}$ resulted in increased intracellular killing of opsonized Staphylococcus aureus by granulocytes and an enhancement of superoxide release upon stimulation with formyl-methionyl-leucyl-phenylalanine in both patients up to $11.1 \pm 6.0$ and $13.5 \pm 7.0 \%$ (mean $\pm \mathrm{SEM}, n=5$ ) of normal controls', mean value in patient 1 and patient 2 , respectively. These data suggested that recombinant human granulocyte colony-stimulating factor treatment enhanced resistance to bacterial infection by stimulation of superoxide generation and increasing the bactericidal capacity of peripheral blood granulocytes. (Pediatr Res 37: 50-55, 1995)

\section{Abbreviations}

ANC, absolute neutrophil counts

FMLP, formyl-methionyl-leucyl-phenylalanine

G-CSF, granulocyte colony-stimulating factor

rhG-CSF, recombinant human G-CSF

CGD, chronic granulomatous disease

KRPD, Krebs-Ringer phosphate buffer containing dextrose

NHS, normal human serum

$\mathrm{O}_{2}^{-}$, superoxide anion

SOD, superoxide dismutase

PHA, phytohemagglutinin

PMA, phorbol myristate acetate

CFU, colony forming unit

$\left[\mathrm{Ca}^{2+}\right]_{\mathbf{i}}$, cytoplasmic free calcium
Human G-CSF, a 177-amino acid glycosylated protein, is one of the growing number of recognized cytokines involved in the regulation of hematopoiesis $(1,2)$. G-CSF preferentially stimulates the growth and development of neutrophils (3). Administration of rhG-CSF to patients with myelodysplastic syndrome, aplastic anemia, and chemotherapy-induced neutropenia was found to increase the absolute neutrophil count, and

Received December 6, 1993; accepted July 12, 1994

Correspondence: Dr. László Maródi, Division of Immunology, Department of Pediatrics, University School of Medicine, Debrecen, P.O. Box 32, H-4012 Debrecen, Hungary.

Supported by grants from the National Science Foundation of Hungary (OTKA 1446) and from the Swiss Red Cross Blood Transfusion Service, Switzerland. to reduce infectious complications (4-7). Recent observations suggest that patients with chronic neutropenia may also benefit from rhG-CSF treatment (8-11). Previously, the treatment of these patients relied on supportive care alone.

The underlying disorder in chronic neutropenia, such as Kostmann's syndrome, cyclic neutropenia, and idiopathic chronic neutropenia, has only partially been characterized. Previous work has shown that the defect of myelopoiesis in these disorders is more likely due to reduced cellular responsiveness to G-CSF or another regulatory defect at the level of the stem cell than to G-CSF deficiency $(11,12)$.

rhG-CSF exerts a variety of in vitro and in vivo effects on neutrophils such as up-regulation of CD11b and CD64 recep- 
tors, priming for enhanced release of reactive oxygen radicals and arachidonic acid metabolites, and increased antibodydependent cellular cytotoxicity (13-17). However, the precise mechanism of action of rhG-CSF in patients with neutropenia is not known.

We report two patients with chronic neutropenia and deficiency of superoxide generation of granulocytes. The unique finding in these patients was the severe respiratory burst defect of granulocytes stimulated with FMLP, which was similar to that of cells from patients with CGD. We found that treatment of these patients with rhG-CSF resulted in marked increases of the bactericidal capacity and superoxide generation by granulocytes isolated from the patients blood.

\section{METHODS}

Isolation of granulocytes. A maximum of $4 \mathrm{~mL}$ of heparinized $(10 \mathrm{U} / \mathrm{mL})$ venous blood was obtained from the patients several times before and during treatment with rhG-CSF. Granulocytes were separated from blood as described (18). Cells were washed and resuspended to a concentration of $5 \times$ $10^{6} / \mathrm{mL}$ in KRPD. The granulocyte suspension contained more than 95\% neutrophils (band-form and segmented neutrophils) as checked by May Grünwald-Giemsa staining in cytocentrifuge preparations. For selected experiments, granulocytes were isolated from patients with CGD or from healthy children or adults. Special attention was paid to avoid lipopolysaccharide contamination throughout the isolation procedure (19).

Bacteria. Staphylococcus aureus (type 42D) was cultured overnight at $37^{\circ} \mathrm{C}$ in Nutrient Broth (Oxoid, London), harvested by centrifugation at $1500 \times g$ for $10 \mathrm{~min}$, washed twice with KRPD, and finally resuspended in KRPD containing $0.1 \%$ gelatin to a concentration of $5 \times 10^{6}$ bacteria/mL (20).

Preopsonization. NHS was prepared from five healthy adults and stored at $-70^{\circ} \mathrm{C}$. Bacteria were preopsonized by incubation of $5 \times 10^{6} \mathrm{~S}$. aureus $/ \mathrm{mL}$ with $10 \%$ serum for 30 min at $37^{\circ} \mathrm{C}$ under rotation ( $4 \mathrm{rpm}$ ), followed by centrifugation and washes in KRPD at $4^{\circ} \mathrm{C}$. The bacteria were finally resuspended to a concentration of $5 \times 10^{6} / \mathrm{mL}(18,20)$.

Measurement of $\mathrm{O}_{2}{ }^{-}$release. The release of $\mathrm{O}_{2}{ }^{-}$from granulocytes was quantitated as the SOD-inhibitable reduction of ferricytochrome $c$ (type III; Sigma Chemical Co., St. Louis, MO) $(21,22)$. FMLP $\left(10^{-7} \mathrm{M}\right)$ or PMA $(500 \mathrm{ng} / \mathrm{mL})$ was added to phagocytic cells $\left(10^{6} / \mathrm{mL}\right)$ in KRPD buffer with 80 $\mu \mathrm{M}$ cytochrome $c$, with or without $50 \mu \mathrm{g} / \mathrm{mL}$ SOD. After 5 to $30 \mathrm{~min}$ of incubation at $37^{\circ} \mathrm{C}$, the reaction was stopped by shaking the tubes in crushed ice followed by centrifugation at $4^{\circ} \mathrm{C}$ for $5 \mathrm{~min}$. Supernatants were transferred to microtiter plates (200 $\mu \mathrm{L} /$ well; Nunc, Fernruf, Denmark) and reduction of ferricytochrome $c$ was measured spectrophotometrically at $550 \mathrm{~nm}$ by using a computerized ELISA reader (Molecular Devices, Menlo Park, CA).

Measurement of phagocytosis. Phagocytosis of S. aureus was measured by incubating $50 \mu \mathrm{L}$ of a phagocytic cell suspension containing $5 \times 10^{6}$ granulocytes $/ \mathrm{mL}$ with an equal volume of a suspension of $5 \times 10^{6}$ bacteria $/ \mathrm{mL}$ in the presence of $10 \% \mathrm{NHS}$ for $60 \mathrm{~min}$ at $37^{\circ} \mathrm{C}$ under rotation $(4 \mathrm{rpm})$. At 0 and $60 \mathrm{~min}$ time points, $25-\mu \mathrm{L}$ aliquots of the mixture were removed and added to ice-cold KRPD $(475 \mu \mathrm{L})$ containing $0.01 \%$ human albumin (Sigma Chemical Co.). The number of viable extracellular bacteria was determined by colony counts (18). The percentage of phagocytosis of $S$. aureus by granulocytes was determined as the decrease in the number of viable extracellular bacteria (18).

Measurement of intracellular killing. Equal volumes of granulocyte suspension $\left(5 \times 10^{6} \mathrm{cells} / \mathrm{mL}\right)$ and preopsonized S. aureus suspension $\left(5 \times 10^{6}\right.$ bacteria/mL) were mixed and incubated at $37^{\circ} \mathrm{C}$ under rotation $(4 \mathrm{rpm})$. Total volume was $100 \mu \mathrm{L}$. After $3 \mathrm{~min}$ of incubation, phagocytosis was stopped by shaking the tubes in crushed ice, and noningested bacteria were removed by differential centrifugation and washes in ice-cold KRPD (18). Next, the phagocytic cells containing ingested bacteria were resuspended to a concentration of $2.5 \times$ $10^{6} / \mathrm{mL}$ and incubated at $37^{\circ} \mathrm{C}$ under rotation $(4 \mathrm{rpm})$. Aliquots of the suspension $(25 \mu \mathrm{L})$ were removed at 0 and $60 \mathrm{~min}$ of incubation, and the granulocytes were lysed by adding $(75 \mu \mathrm{L})$ ice-cold distilled water containing $0.01 \%$ albumin and pipetting the suspension for $1 \mathrm{~min}$. The percentage of bacteria that had been killed was determined by colony counting in duplicate (18).

Hematopoietic progenitor cell assay. CFU were determined in soft agar cultures of bone marrow samples aspirated for diagnostic purposes (23). Triplicate cultures of bone marrow cells $\left(1-2 \times 10^{6}\right.$ mononuclear cells $\left./ \mathrm{mL}\right)$ were plated in Petri dishes. The source of CSF was $0.2 \mathrm{~mL}$ of conditioned medium of $4 \times 10^{6}$ human blood mononuclear cells. PHA-stimulated leukocyte-conditioned media were prepared from healthy adult donors. Cells were cultured for $5 \mathrm{~d}$ in McCoy's medium containing $15 \%$ autologous serum, $17 \mu \mathrm{g}$ PHA/mL and $5 \mu \mathrm{g}$ levamisol $/ \mathrm{mL}$.

\section{CASE REPORTS}

Patient 1. This 7-y-old girl had been repeatedly hospitalized because of bacterial infections of the skin, middle ear, gingiva, lung, and bone since the age of $2 \mathrm{mo}$. By her sixth birthday, she had spent $514 \mathrm{~d}$ in hospital. At the age of $2 \mathrm{y}$, bilateral mastoidectomy had to be performed in the course of chronic, purulent otitis media and mastoiditis. Recurrent otitis media caused predominantly by $S$. aureus and Pseudomonas aeruginosa led to severe hearing loss, impaired speech development, and mental retardation. Deep-seated skin infections and paronychia caused by $S$. aureus required surgical management on two occasions. At the age of $5 \mathrm{y}$, she developed cellulitis in the fourth digit of the right leg, which led to osteomyelitis of the involved toe and required amputation of the distal phalanx. The chronic gingivostomatitis resulted in gingival hypertrophy and premature loss of both deciduous and permanent teeth. The chronic infections were complicated by hypoproteinemia, anemia, and failure to thrive. Kidney and liver function tests and ultrasonography of the liver and spleen were normal. Bone marrow morphology disclosed maturation arrest at the promyelocyte-myelocyte stage but indicated an increased normoblastic erythropoiesis and thrombocytopoiesis. The diagnosis of chronic neutropenia with defective activity of the granulocyte 
respiratory burst was made at the age of $5 \mathrm{y}$, when $\mathrm{O}_{2}^{-}$ generation by granulocytes was measured repeatedly (Fig. 1A).

The parents of this patient are unrelated and healthy. Her 4-y-old sister has had recurrent upper respiratory tract infections without detectable immunodeficiency (data not shown).

Patient 2. This 15-mo-old girl presented with frequent episodes of fever, purulent otitis media, tonsillitis, bronchitis, and pneumonia beginning during the first 4 mo of life. At the age of $1 \mathrm{y}$, bilateral mastoidectomy had to be performed in the course of chronic otitis media. Kidney and liver function tests and abdominal ultrasonography were normal. Bone marrow morphology findings indicated maturation arrest at the promyelocyte-myelocyte stage and an increased number of monocytes and eosinophilic granulocytes, and an increased normoblastic erythropoiesis. The diagnosis of chronic neutropenia with an associated respiratory burst defect was made by measurements of $\mathrm{O}_{2}{ }^{-}$release by granulocytes at the age of $13 \mathrm{mo}$ (Fig. 1B).

The patient's brother had myelodysplastic syndrome and died at the age of $8 \mathrm{y}$; her sister of $9 \mathrm{y}$ and her unrelated parents are healthy.

A

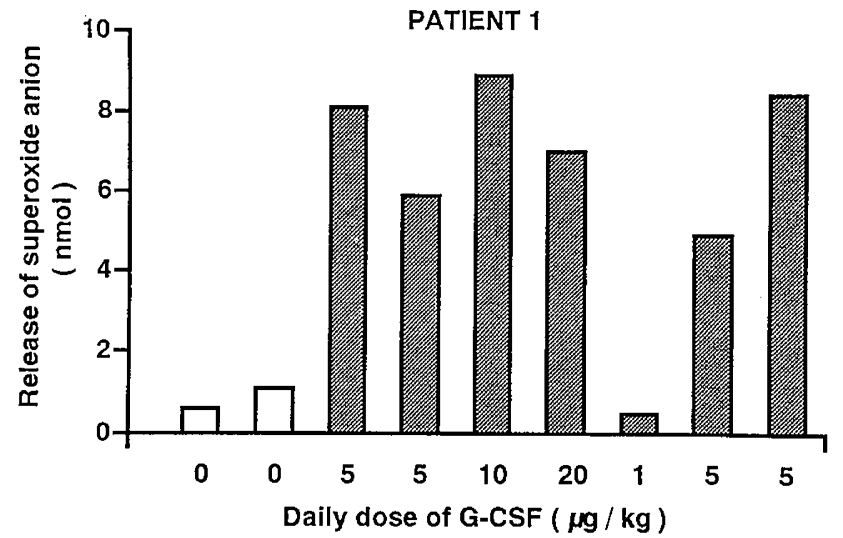

B

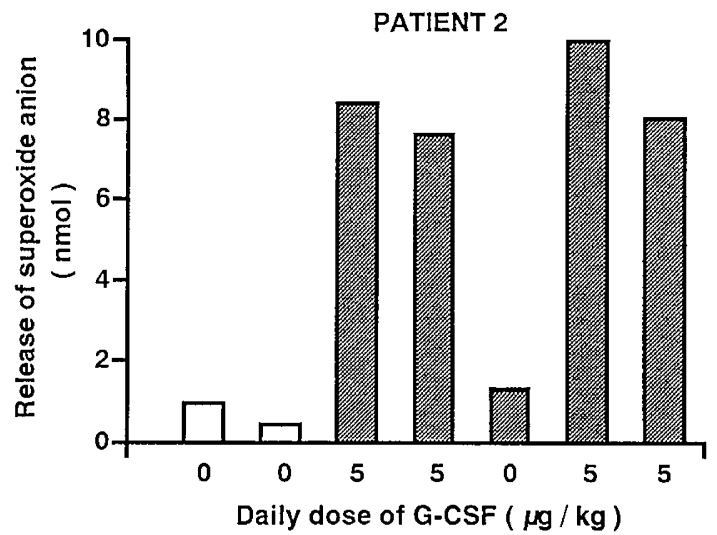

Figure 1. Release of $\mathrm{O}_{2}{ }^{-}$by $2 \times 10^{5}$ granulocytes before treatment (open columns) and during treatment (hatched columns) with varying doses of rhG-CSF for 5 or more preceding $d$ on the same dose. The heights of the columns represent data of single, one-tube measurements. Blood was drawn before administration of the daily dose of rhG-CSF. Cells were stimulated with $10^{-7} \mathrm{M}$ FMLP for $5 \mathrm{~min}$. Release of $\mathrm{O}_{2}{ }^{-}$by granulocytes from normal controls was $62 \pm 17 \mathrm{nmol}$ (mean $\pm \mathrm{SEM} ; n=6$ ).
She exhibits slight esotropia, impairment of abduction, and retraction on adduction of the right globe, which are characteristic features of Duane syndrome, a rare disorder of eye movement (24).

\section{RESULTS}

Clinical responses. Therapy with rhG-CSF was well tolerated without toxicity and led to considerable clinical improvement and reduction of infectious complications over periods of 6 and $3 \mathrm{mo}$ in patients 1 and 2, respectively. The severe gingivostomatitis in patient 1 resolved dramatically after $3 \mathrm{wk}$ of rhG-CSF therapy without administration of antibiotics. Contrary to delayed recoveries from infections before treatment in patient 2, otitis media and pneumonia resolved rapidly by administration of $\mathrm{rhG}-\mathrm{CSF}(5 \mu \mathrm{g} / \mathrm{kg} / \mathrm{d})$ and antibiotics. After 7-8 wk of rhG-CSF treatment, the concentration of serum Ig decreased markedly in both patients, which is compatible with resolution of chronic infection (Fig 2).

Peripheral blood counts and $\boldsymbol{C F U}$. The initial numbers of granulocytes were 1.0 and $0.3 \times 10^{9} / \mathrm{L}$ in patients 1 and 2 , respectively (Fig. 3). After 7-10 d of treatment, the ANC increased. After achieving a peak, the ANC decreased in both patients. In patient 1 , increasing the daily dose of rhG-CSF resulted in transient increases in ANC following by a gradual decrease in neutrophil number. Data in Figure 3 indicate the lack of definite relationships between ANC and the dosage of rhG-CSF.

Adrenalin stimulation tests $(0.01 \mathrm{mg}$ adrenalin $/ \mathrm{kg}$, s.c.) were performed in both patients and showed 31 and $35 \%$ increases of ANC, respectively, over a period of $2 \mathrm{~h}$. Hydrocortisone stimulation test ( $2 \mathrm{mg}$ hydrocortisone/kg, i.v.) showed 40 and $47 \%$ increases of ANC, respectively, over a period of $24 \mathrm{~h}$. These data suggested that neutropenia in either of these patients was not due to increased margination of granulocytes or storage pool defect (25).

Soft agar cultures of bone marrow before treatment with rhG-CSF yielded no colonies in patient 1 and $14 \pm 7 \mathrm{CFU} / 10^{5}$

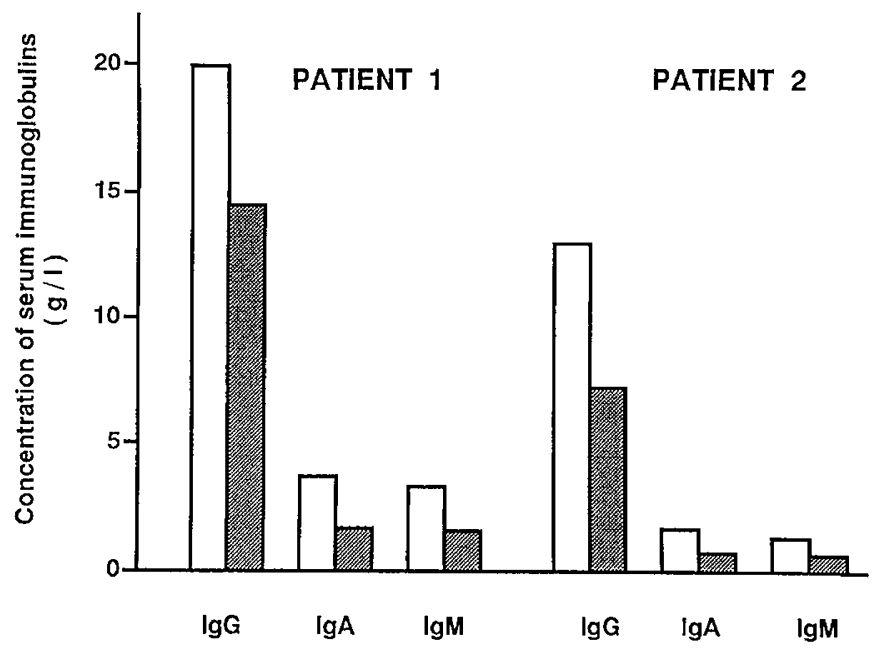

Figure 2. Serum Ig concentrations were measured 3-5 d before treatment (open columns) and 7-8 wk after treatment (hatched columns) with rhG-CSF. 

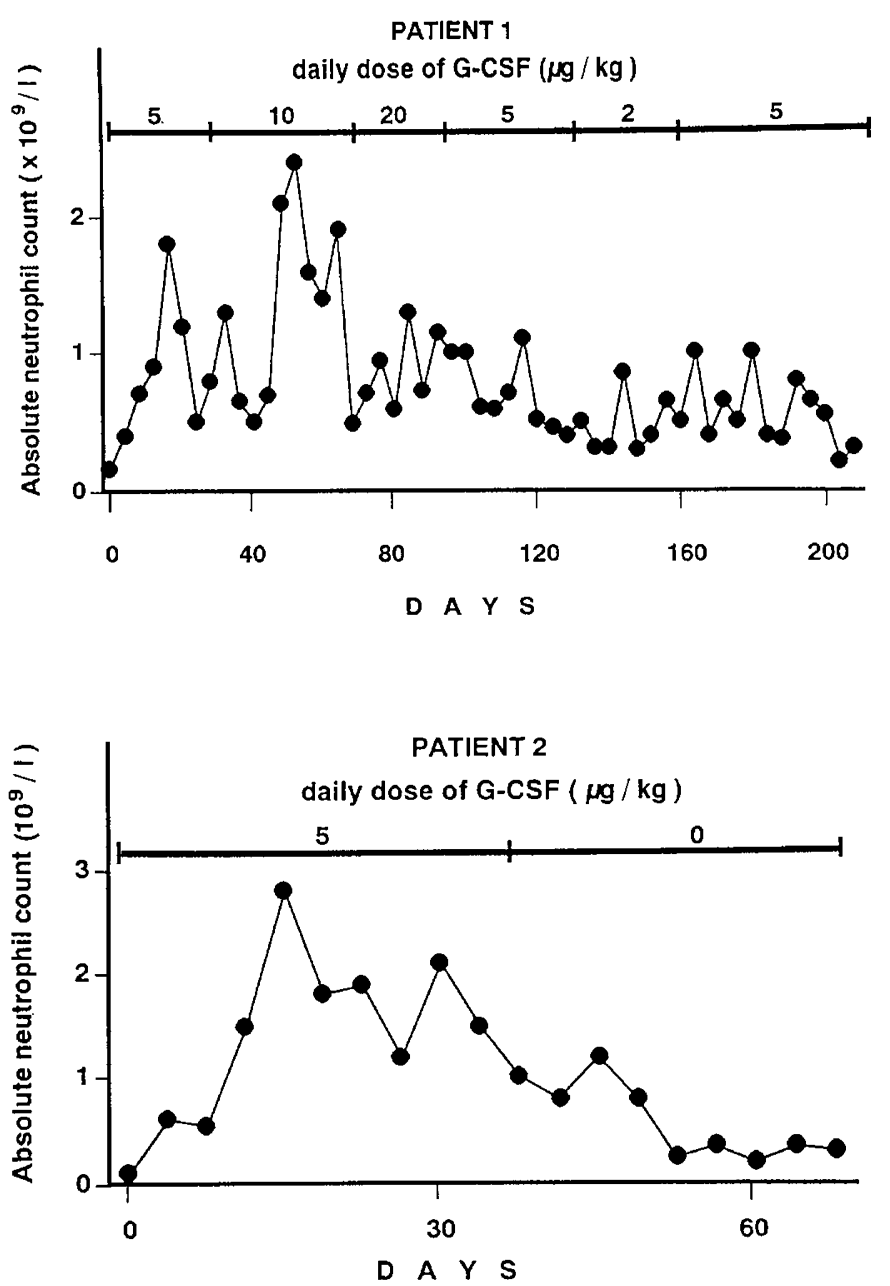

Figure 3. ANC in patients treated with rhG-CSF. Vertical bars and numbers indicate the number of days since start of treatment and doses of rhG-CSF, respectively.

bone marrow cells in patient 2 , compared with $28.4 \pm 5.1$ $\mathrm{CFU} / 10^{5}$ bone marrow cells in controls (mean $\pm \mathrm{SEM}, n=$ 33).

Phagocytosis and intracellular killing of S. aureus by granulocytes. Phagocytosis and killing of fully opsonized $S$. aureus by granulocytes were measured before and during treatment with rhG-CSF. The extent of ingestion of bacteria before treatment was comparable to that of controls in both patients (Table 1). There were no differences in the phagocytosis of $S$. aureus by granulocytes isolated before or during rhG-CSF treatment. However, granulocytes from either patient were unable to kill bacteria efficiently before treatment (Table 1); significant improvement in the bactericidal activities of granulocytes could be detected during rhG-CSF treatment ( $p<$ 0.001 in both patients). The daily dose of rhG-CSF did not correlate with the killing capacities of granulocytes, and administration of rhG-CSF at $20 \mu \mathrm{g} / \mathrm{kg} / \mathrm{d}$ did not result in proportionally increased killing by granulocytes compared with killing at doses of $5 \mathrm{~g} / \mathrm{kg} / \mathrm{d}$.

Respiratory burst activation in granulocytes. We measured FMLP-induced $\mathrm{O}_{2}{ }^{-}$release by granulocytes in an attempt to define the biochemical basis of greater killing of $S$. aureus by these cells from rhG-CSF-treated patients. As shown in Figure
Table 1. Phagocytosis and intracellular killing of S. aureus by granulocytes from neutropenic patients

\begin{tabular}{cccccc}
\hline & \multicolumn{2}{c}{$S$. aureus ingested } & & \multicolumn{2}{c}{$S$. aureus killed $\dagger$} \\
\cline { 2 - 3 } \cline { 5 - 6 } & $\begin{array}{c}\text { Before } \\
\text { treatment }\end{array}$ & $\begin{array}{c}\text { During } \\
\text { treatment }\end{array}$ & & $\begin{array}{c}\text { Before } \\
\text { treatment }\end{array}$ & $\begin{array}{c}\text { During } \\
\text { treatment }\end{array}$ \\
\hline 1 & $(\%)$ & $(\%)$ & & $(\%)$ & $(\%)$ \\
\hline 2 & $96 \pm 8$ & $86 \pm 8$ & & $3 \pm 2$ & $62 \pm 9$ \\
\hline
\end{tabular}

All data represent mean $\pm \operatorname{SEM}(n=3$ or more) and are expressed as percentages of normal controls' mean value $(n=6)$ before and during treatment with $5 \geq \mu \mathrm{g} / \mathrm{kg}$ rhG-CSF for 5 or more preceding days.

* Determined as the percentage decrease of the number of viable extracellular microorganisms after a 60 -min incubation of granulocytes and bacteria in the presence of $10 \%$ normal human serum.

† Determined as the percentage decrease of the number of viable intracelIular microorganisms after a 60 -min incubation of granulocytes containing ingested bacteria.

1 , administration of rhG-CSF for at least $5 \mathrm{~d}$ at doses of 5 $\mu \mathrm{g} / \mathrm{kg} / \mathrm{d}$ resulted in a 6-9 times larger amount of $\mathrm{O}_{2}{ }^{-}$released compared with values before treatment. No further increase in $\mathrm{O}_{2}{ }^{-}$release by granulocytes was found at daily doses of 10 or $20 \mu \mathrm{g} / \mathrm{kg} \mathrm{rhG-CSF}$ in patient 1 . However, when the daily dose of $\mathrm{rhG}-\mathrm{CSF}$ was decreased to $1 \mu \mathrm{g} / \mathrm{kg} / \mathrm{d}$ for more than $1 \mathrm{wk}$ in patient 1 or treatment was ceased for $3 \mathrm{wk}$ in patient 2 , the amount of $\mathrm{O}_{2}{ }^{-}$released by granulocytes decreased to values measured before treatment (Fig. 1). Incubation of granulocytes with FMLP over a period of $30 \mathrm{~min}$ did not result in a significantly higher amount of superoxide compared with data obtained with $5 \mathrm{~min}$ of incubation (data not shown). Contrary to findings with FMLP, the PMA-induced $\mathrm{O}_{2}{ }^{-}$release by granulocytes from patient 1 and patient 2 was $81 \pm 12$ and 94 $\pm 11 \%$ of normal controls', mean value, respectively (mean \pm $\mathrm{SEM}, n=3)$.

Granulocytes from two patients with X-linked CGD, who were free of acute infection, were also studied. The $\mathrm{O}_{2}{ }^{-}$ released by CGD cells under the experimental conditions used in this study was $1.8 \pm 0.6$ and $2.4 \pm 1.8 \%$ (mean \pm SEM, $n=$ 3 in both patients) compared with normal controls', mean value $(n=7)$. Negligible killing of $S$. aureus by CGD cells could be detected over $60 \mathrm{~min}$ of incubation $(2.5 \pm 1.4$ and $5.2 \pm 2.1 \%$ of normal controls', mean value in patient 1 and patient 2 , respectively $(n=3)$, whereas phagocytosis of opsonized staphylococci was comparable to that of age-matched controls (data not shown).

\section{DISCUSSION}

We report two patients with chronic neutropenia and severe deficiency of $\mathrm{O}_{2}^{-}$release by granulocytes. Bone marrow morphology in one of the patients (patient 2) fulfilled one of the criteria of Kostmann's syndrome, namely maturation arrest at the promyelocyte-myelocyte stage, but the number of peripheral blood granulocytes exceeded $200 / \mu \mathrm{L}$, which could not be expected in this syndrome (26). Another unusual finding in this patient was the association of chronic neutropenia with Duane syndrome. This syndrome, a rare congenital defect of eye movement, can occur alone or in association with other disorders (24). To our knowledge, occurrence of chronic neutrope- 
nia in association with Duane syndrome has not been published.

Granulocytes from both patients exhibited a severe impairment of activation of the respiratory burst upon stimulation with FMLP. It has been reported that a mild to moderate decrease of $\mathrm{O}_{2}{ }^{-}$generation can occur in patients with chronic neutropenia $(8,27)$. Granulocytes from our patients showed comparable FMLP-induced superoxide generation and functional activities to those of cells from CGD patients (Fig. 1). Contrary to CGD cells (28), however, granulocytes from our neutropenic patients could be induced with PMA to release $\mathrm{O}_{2}{ }^{-}$, a finding that ruled out the possibility that the patients had CGD. Based on these observations we believe that our patients with chronic neutropenia and severe defect of $\mathrm{O}_{2}{ }^{-}$generation have a distinct disease entity.

In selected experiments, we studied $\mathrm{O}_{2}{ }^{-}$generation of the patients', granulocytes stimulated with preopsonized staphylococci (21). The experiments gave similar results to those obtained with FMLP (the amount of $\mathrm{O}_{2}{ }^{-}$generated by $2.5 \times 10^{5}$ cells over a period of $30 \mathrm{~min}$ was $6.5 \pm 3.4$ and $8.2 \pm 4.3 \%$ of normal controls', mean value in patient 1 and patient 2 , respectively $n=$ 3). These data suggest that in the patients granulocytes exhibit a signal transduction defect when surface receptors are involved in the stimulation of the respiratory burst.

In vivo effect of rhG-CSF on the microbicidal activity of granulocytes in patients with chronic neutropenia has not been reported to our knowledge. We report that rhG-CSF treatment in patients with chronic neutropenia and defective superoxide generation may result in an enhanced capacity of granulocytes to kill viable $S$. aureus. These functional changes may be especially important in patients whose ANC increases only moderately during rhG-CSF treatment, and may help our understanding of the mechanism of action of rhG-CSF in patients with chronic neutropenia.

Stimulus-response coupling in phagocytic cells stimulated with FMLP or opsonized particles involves receptor binding, an increase in $\left[\mathrm{Ca}^{2+}\right]_{\mathrm{i}}$ and release of $\mathrm{O}_{2}{ }^{-}$and other reactive oxygen intermediates $(29,30)$. Granulocytes from patients with chronic neutropenia have been reported to have abnormal regulation of signal transduction pathways such that their granulocytes do not respond to FMLP with an increase in $\left[\mathrm{Ca}^{2+}\right]_{\mathrm{i}}$ (31). Treatment with rhG-CSF has been reported to restore the ability of granulocytes in such patients to respond to FMLP stimulation with an increase in $\left[\mathrm{Ca}^{2+}\right]_{i}$ (32). These findings and the observations described are in agreement and suggest that an impairment of a calcium transient and $\mathrm{O}_{2}{ }^{-}$ generation may contribute to impaired host defense in patients with quantitative neutrophil deficiency.

Recent observations suggest that patients with chronic neutropenia have no defect in G-CSF production or in expression of G-CSF receptor binding sites on neutrophil granulocytes, but a defective response of neutrophil precursors to endogenous or exogenous G-CSF may play a role $(14,32)$. Our findings further emphasize the importance of the effect of G-CSF treatment on functional and metabolic activities of peripheral blood granulocytes in neutropenic patients.
Acknowledgments. The authors thank Dr. Ilona Benkô for help with bone marrow culture, Dr. János Ujszászi (HoffmannLa Roche, Budapest) for the gift of rhG-CSF, Mária Fülöp and Ildikó Bereczki for excellent technical assistance, and Dr. Richard B. Johnston, Jr. for critically reading this manuscript.

\section{REFERENCES}

1. Nicola NA, Metcalf D, Matsumoto M, Johnson GR 1983 Purification of a factor inducing differentiation in murine myelo-monocytic leukemia cells: identification as granulocyte-colony-stimulating factor (G-CSF). J Biol Chem 258:9017-9023

2. Lieschke GJ, Burgess AW 1992 Granulocyte colony-stimulating factor and granulocyte-macrophage colony-stimulating factor. N Engl J Med 327:28-35

3. Cohen AM, Zsebo KM, Inoue H 1987 In vivo stimulation of granulopoiesis by recombinant human granulocyte colony-stimulating factor. Proc Natl Acad Sci USA 84:2484-2488

4. Negrin RS, Haeuber DH, Hagler A, Olds L, Donlon T, Souza LM, Greenberg PL 1989 Treatment of myelodysplastic syndromes with recombinant human granulocyte colony-stimulating factor. A phase I-II trial. Ann Intern Med 110:976-984

5. Kojima S, Fukuda M, Miyajima Y, Matsuyama T, Horibe K 1991 Treatment of aplastic anemia in children with recombinant human granulocyte colony-stimulating factor. Blood 77:937-941

6. Lindemann A, Herrmann F, Oster W, Haffner G, Meyenburg W, Souza LM, Mertelsmann R 1989 Hematologic effects of recombinant human granulocyte colonystimulating factor in patients with malignancy. Blood 74:2644-2650

7. Morstyn G, Souza LM, Keech J, Sheridan W, Campbell L, Alton NK, Green M, Metcalf D, Fox R 1988 Effect of granulocyte colony stimulating factor on neutropenia induced by cytotoxic chemotherapy. Lancet 1:667-672

8. Boxer LA, Hutchinson R, Emerson S 1992 Recombinant human granulocyte colonystimulating factor in the treatment of patients with neutropenia. Clin Immunol Immunopathol 62:S39-S45

9. Welte K, Zeidler C, Reiter A, Müller W, Odenwald E, Souza L, Riehm H 1990 Differential effects of granulocyte-macrophage colony-stimulating factor and granulocyte colony-stimulating factor in children with severe congenital neutropenia. Blood 75:1056-1063

10. Bonilla MA, Gillio AP, Ruggeiro M, Kernan NA, Brochstein JA, Abboud M, Fumagalli L, Vincent M, Gabrilove JL, Welte K, Souza LM, O'Reilly RJ 1989 Effect of recombinant granulocyte colony-stimulating factor on neutropenia in patients with congenital agranulocytosis. N Engl J Med 320:1574-1580

11. Vadhan-Raj S, Jeha SS, Buescher S, LeMaistre A, Yee G, Lu L, Lloreta J, Hoots WK, Hittelman WN, Gutterman JU, Broxmeyer HE 1990 Stimulation of myelopoiesis in patients with congenital neutropenia: biology and nature of response to recombinant human granulocyte-macrophage colony-stimulating factor. Blood 75:858-864

12. Mempel K, Pietsch T, Menzel T, Zeidler C, Welte K 1991 Increased serum levels of granulocyte colony-stimulating factor in patients with severe congenital neutropenia. Blood 77:1919-1922

13. Yuo A, Kitagawa S, Ohsaka A, Saito M, Takaku F 1990 Stimulation and priming of human neutrophils by granulocyte colony-stimulating factor and granulocytemacrophage colony-stimulating factor: qualitative and quantitative differences. Biochem Biophys Res Commun 171:491-497

14. Repp R, Valerius Th, Sendler A, Gramatzki M, Iro H, Kalden JR, Platzer E 1991 Neutrophils express the high affinity receptor for IgG (FcRI, CD64) after in vivo application of recombinant human granulocyte colony-stimulating factor. Blood $78: 885-889$

15. Nathan CF 1989 Respiratory burst in adherent human neutrophils: triggering by colony-stimulating factors CSF-GM and CSF-G. Blood 73:301-306

16. Avalos BR, Gasson JC, Hedvat C, Quan SG, Baldwin GC, Weisbart RH, Williams RE, Golde DW, DiPersio JF 1990 Human granulocyte colony-stimulating factor: biologic activities and receptor characterization on hematopoietic cells and small cell lung cancer cell lines. Blood 75:851-857

17. Ohsaka A, Kitagawa S, Sakamoto S, Miura Y, Takanashi N, Takaku F, Saito M 1989 In vivo activation of human neutrophil functions by administration of human granulocyte colony-stimulating factor in patient with malignant lymphoma. Blood 74:2743-2748

18. Maródi L, Leijh PCJ, van Furth R 1983 A micromethod for the separate evaluation of phagocytosis and intracellular killing of Staphylococcus aureus by human granulocytes and monocytes. J Immunol Methods 57:353--361

19. Haslett C, Guthrie LA, Kopaniak MM, Johnston Jr RB, Henson PM 1985 Modulation of multiple neutrophil function by preparative methods or trace concentrations of bacterial lipopolysaccharide. Am J Pathol 119:101-110

20. Maródi L, Leijh PCJ, Braat A, Daha MR, van Furth R 1985 Opsonic activity of cord blood sera against various species of microorganisms. Pediatr Res 19:433-436

21. Maródi L, Kalmár A, Karmazsin L 1990 Stimulation of the respiratory burst and promotion of bacterial killing in granulocytes by intravenous immunoglobulin preparations. Clin Exp Immunol 79:164-169

22. Maródi L, Forehand JR, Johnston Jr RB 1991 Mechanisms of host defense against Candida species: II. Biochemical basis for killing of Candida by mononuclear phagocytes. J Immunol 146:2790-2794

23. Pike BL, Robinson WA 1970 Human bone marrow colony growth in agar gel. J Cell Physiol 76:77-85

24. Kalpakian B, Choy AE, Sparkes RS 1988 Duane syndrome associated with the cat-eye syndrome and mosaicism for a supernumerary chromosome probably derived from number 22. J Pediatr Ophthtalmol Strab 25:293-297 
25. Shyur S, Hill HR 1991 Immunodeficiency in the 1990s. Pediatr Infect Dis J 10:595-611

26. Kostmann $\mathrm{R} 1956$ Infantile genetic agranulocytosis. Acta Paediatr Scand 45:1-7

27. Weston B, Todd RF, Axtell R, Balazovich K, Stewart J, Locey BJ, Mayo-Bond L Loos P, Hutchinson R, Boxer LA 1991 Severe congenital neutropenia: clinical effects and neutrophil function during treatment with granulocyte colony-stimulating factor. J Lab Clin Med 117:282-290

28. Woodmman RC, Erickson RW, Rae J, Jaffe HS, Curnutte JT 1992 Prolonged recombinant interferon- $\gamma$ therapy in chronic granulomatous disease: evidence against enhanced neutrophil oxidase activity. Blood 79:1558-1562

29. Korchak HM, Vienne K, Rutherford LE, Wilkenfeld C, Finkelstein MC, Weissmann G 1984 Stimulus response coupling in the human neutrophil. II. Temporal analysis of changes in cytosolic calcium and calcium efflux. J Biol Chem 259:4076-4082
30. Maródi L, Schreiber S, Anderson DC, MacDermott RP, Korchak HM, Johnston Jr RB 1993 Enhancement of macrophage candidacidal activity by IFN-gamma: increased phagocytosis, killing and calcium signal mediated by a decreased number of mannose receptors. J Clin Invest 91:2596-2601

31. Elsner J, Roesler J, Emmendorffer A, Lohmann-Matthes ML, Welte K 1993 Abnormal regulation in the signal transduction in neutrophils from patients with severe congenital neutropenia: relation of impaired mobilization of cytosolic free calcium to altered chemotaxis, superoxide anion generation, and F-actin content. Exp Hematol 21:38-46

32. Kyas U, Pietsch T, Welte K 1992 Expression of receptors for granulocyte colonystimulating factor on neutrophils from patients with severe congenital neutropenia and cyclic neutropenia. Blood 79:1144-1147 